\title{
Exploring Metropolitan Governance: The Balance between the Institutional Context and the Planning Practices
}

\author{
Rui Florentino,", José Miguel Fernández Güell² \\ ${ }^{1}$ School Gallaecia, CIESG Research Centre, Portugal \\ ${ }^{2}$ School of Architecture, DUYOT, Polytechnic University of Madrid, Spain
}

Copyright $\bigcirc 2017$ by authors, all rights reserved. Authors agree that this article remains permanently open access under the terms of the Creative Commons Attribution License 4.0 International License

\begin{abstract}
The institutional mark and the planning practices can be the two principal dimensions for improving metropolitan governance, addressing the running challenges of several greater cities. Regarding the South West European capital regions, what are the main differences and innovations in their currently processes and models? This paper proposes an applied framework to present the metropolitan governance analysis. Through a comparative case study methodology, various elements and interviews were qualitatively measured, in the regions of Madrid, Barcelona, Paris and Lisbon. The conclusion finds a tendency to balance, between the efforts on those major dimensions of the metropolitan governance system, which does not prevent different paths to register: for example Ile-de-France has developed good initiatives in the technical processes, which then require some adjustments in the political mark, while Madrid had in recent years "less activity", in result of his institutional stability. If it can be obvious that institutional reforms lead to new challenges in planning practices, the research argues that the opposite direction is also true - that operational processes give rise to structural changes, proving their corresponding influence on responsibilities, resources and leadership, given by the political context.
\end{abstract}

Keywords Metropolitan Governance, Spatial Planning, Comparative Analysis

\section{Introduction}

The urban territories scale of analysis is progressively growing, towards the surrounded metropolitan region, given that, currently, more than half of the world's population lives less than one hour from a large [1]. It is in fact generally acknowledged, from different academic and professional perspectives, an increasing interest on urban planning and land use management, fields of study which are now facing relevant challenges. In Europe, due to two complementary phenomena: on one hand, a progressive fragmentation of competences and the needs to improve their coordination, especially for the public authorities [2]; on the other, the competition between large cities, as collective stakeholders, that may take over the role of the states as economic leaders on a global scale $[3,4]$. Most of the European capital cities constitute nowadays an exportable cultural "brand". They have global promotion departments and pay particular attention to the rankings compiled by the rating agencies. It is thus understandable that, in order to face those challenges, we witness conceptual changes in the metropolitan territorial governance processes.

Certainly, a "vertically structured" public administration is now "updated". It is therefore important that urban and regional governments will be able to adapt easily to the present technical and political demands, with more citizenship participation and horizontal collaboration, in result of shared decision-processes and responsibilities [5]. In other words, we could say that the new governance paradigm acknowledges from the advantage of cooperation with citizens and socio-economic stakeholders.

In the state of art, the different elements of territorial governability were previously presented into three levels: the means at the base (technology, resources and social capital), which support the carrying out functions, then the operational processes and organizational skills, that facilitates the development of the strategy, at the top [6]. Similar to this reading, Mireia Belil [7] showed that the success of a management strategy depends from competences, capacities and, obviously, democracy. "More than just land management that designs the territory, this is creating an informational and coordination mechanism resulting in three essential elements: capacity, technical information and knowledge; competence, the power and 
instruments for taking action; and democracy, which enables debate and participation."

Building on these endeavors for understanding the governance capacity, Heinelt and Kubler [8] looked at the presence of different typologies in the land management entities in European countries: from the British system, which has greater experience in adapting to the metropolitan "dimension", to the German and Scandinavian models, which are also decentralized, but with greater political power at the regional level, and also the Southwest European countries, where local administrations have perhaps excessive weight, but which may configure innovative organizational solutions. The literature review agrees that "achieving an integrated territorial strategy at the urban region level depends, not only on having the necessary policies and instruments, but also on the existence of an adequate institutional context" [9].

The factors that condition the territorial metropolitan governance would thus seem to result from two sets of elements - one related with the mark of public policies, named "the institutional context", and another linked with the territorial practices in terms of the operational planning processes [10]. The administrative dimension includes the regulatory competences, the human, economic and technological resources and the political and democratic leadership. The second group, technical in nature, includes participation and social capital, the territorial strategy and also the cooperation for important projects. The present article aims to explore this metropolitan governance system, taking the Lisbon region in a comparative analysis with the closer European major cities: Madrid, Barcelona and Paris.

In the following section it is explained the conceptual framework used in carrying out the research. The methodology was based in three tools: contrast of previous relevant work in the theme, interview with twenty-two regional stakeholders (see acknowledgments) and the participation in the advisory technical team for the revision of the Lisbon Metropolitan Plan (first author).

\section{Framework}

In order to realize the goal of analyzing the governance capacities in metropolitan areas, it is necessary to first define the technical and political processes that are the object of study. As already ascertained, one can identify factors that have to do with the institutional governance dimension and others that are more integrated in the operational planning practices. This conceptual difference allowed us to design a framework model that associates the two main dimensions of governance. In the first one, the processes of competences, territorial legislation, resources, democracy and leadership present certainly reforms in the institutional context. From the other dimension, the processes of participation, creation of more social capital, territorial strategy and cooperation for the implementation of major projects, can be innovative from the planning methods perspective.

The figure 1 presents the conceptual model for the analysis of governance processes. It shows that the relationship between contextual reforms, on one hand, and innovation of practices, on the other, results in four different positions:

a. The position A displays the lack of change dynamics, both in the institutional governance context and in the operational planning processes. It characterizes the more stable regions;

b. The position B shows the regions that really commit to structural change, for example in terms of legal competences, resources and in the forms of electing territorial powers, even if they retain their usual practices in operational planning processes;

c. The position C: identifies those regions which, despite their problems, maintain the administrative model while are making efforts to innovate in planning practices through greater participation and creation of social capital, for example with cooperation agreements on strategic plans and territorial projects that advance metropolitan and regional development;

d. And the position D reflects those regions that are most capable of managing important changes at both dimensions, the institutional context and the operational processes of territorial governance

The initially hypothesis indicated in the figure suggests that the current responses to the challenges of metropolitan regions governance are shifting from position B towards position $\mathrm{C}$, maybe because these regions are progressively strengthening their assets in terms of planning practices, thus overcoming the need to change, in advance, their political and institutional model, which is now more stabilized. This confirms what some authors refer to as the "institutional fallacy", given the insistence on the "need to have new administrative mechanisms, perhaps an example of the belief shared by aides that the best way to resolve public problems is to add new entities to the administrative machine (...) Pursuant to this institutional fallacy, the adding of new structures serves as a substitute for real reform" [11].

With the purpose of discussing this argument in a comparative perspective, we reflect on the processes that are currently underway, on the basis of 3 contrasting tools: documental sources (analysis of other research work, laws, plans, etc.); interviews with 22 experts; and directly the professional experience, due to the participation in the technical advisory team for the Lisbon Metropolitan Plan attempt to revision in 2009 and 2010.

Considering the institutional dimension of metropolitan governance, the most important challenges are now listed in detail. These include regulatory simplification in the planning system, decentralization of competences, also the forfeiting of certain local responsibilities to metropolitan scale, improvement in human resources for coordination at 
that level, democratic legitimacy and the strengthening of the political leadership, likewise at the supra-municipal level.

- The simplification of the spatial planning legal framework is without doubt a useful process, as the accumulation of legislation reveals contradictory objectives for the implementation of plans, thus contributing to a situation where urban management becomes an open field to juridical interpretation of rules, with consequences for metropolitan governance.

- The decentralization of a number of central administration powers to the metropolitan level is explained by the principle of "subsidiarity", which means that the decision making should be carried out at the closest level to the citizens, so that the problem can be solved effectively. It does not make sense for the State to retain responsibilities that are better managed by local entities that have better knowledge of the territorial problems.

- In the counter-direction to this decentralization, the transfer of certain municipal powers to the metropolitan level could likewise be also useful. Indeed, excessive fragmentation in the form of local territorial strategies does not help planning, which result from a better comprehensive perspective, reinforcing the principle of efficiency.

- More resources for the technical coordination at the metropolitan level are justified by the fact that the problems of these regions are interlinked, with particular emphasis on the coordination between urban planning and different networks, including public transport. A technical office that's capable of running the higher level plans and simultaneously inform several municipal proposals must have the appropriate economic and technological resources, in order to pursue their competences.

- Recognizing the democratic legitimacy of a metropolitan level is also an elementary process in implementing public policies on that scale. Indeed, the citizens who commute daily across the metropolitan space in their everyday life should be able to elect directly a government at that level. After the municipality where they have officially residence, that's the geographic scale that most influences their quality of life.

- Addressing precisely this capacity of territorial governance, there is an opportunity to "build" a leadership at that metropolitan level. Even if such leadership could be a political threat to the central government and to the capital city, it is certainly good news for the regional planning, within the framework of limited and shared powers.

- Depending on the legal framework and territorial bodies in each region, the reforms of the political context indeed impact the planning operational processes, but they should not be overvalued, given that it is true that efforts towards innovation can be found in any institutional model. Alongside with the structural changes, it is therefore of interest to reflect on the planning practices and understand their application, or whether why they can be processes currently paralyzed. The most important elements in this dimension are the entrepreneurial initiatives, the citizen participation, the integration of strategies in planning, the assessment of territorial plans and their alternatives and the voluntary cooperation between the municipalities in the implementation of major projects.

Promoting the social capital for land use management requires that the socio-economic agents are willing to take initiatives and influence the decision-making processes, because in today's economy good connectivity and the surrounding urban environment are relevant conditions in the whole metropolitan region.

- Simultaneously, the civic participation is growing, either in professional forums or other more informal collectives. The environmental NGOs are already important agents, but there is also an increasing confidence to citizens became involved in the urban and territorial organization processes, which furthers the dissemination of planning information and the public discussion of different proposals.

- The territorial strategy must therefore integrate the concerns of the socio-economic agents and citizens, in responding to the challenges in achieving development. One thus needs a synthetic and coherent plan (as in the French terminology), that will become more governable with the increased balance of the sectoral goals that other public departments have established for the same region.

- In the planning usual follow-up steps (information, analysis and proposal), the assessment and monitoring are frequently not carried out. Although, the best practices show that they are basic conditions for the territorial strategies subsequent revision and furthering adherence to the new metropolitan objectives.

- The assessment of different alternatives in projects that have a high impact at the metropolitan level, as transport, is already a government procedure in order to face legal and environmental quality requirements. However, it sometimes gives rise to political conflicts that more in-depth technical knowledge would help to resolve.

- These governance operational elements require also voluntary cooperation amongst the local bodies, giving a bottom-up direction to the planning methods. Indeed, the implementation of complementary projects in any metropolitan strategy heavily depends on agreements between neighboring municipalities.

\section{Application to Case Studies}

With the purpose of exploring the governance capacities, 
it is possible then to discuss the recent above mentioned processes in a selected number of metropolitan regions. Once the conceptual framework of the research has been presented, this territorial governance system is studied in a comparative analysis. The assessment of processes which are underway enables us to determinate the theoretical position of each region in the conceptual model.

The analysis of the implementation of that list of twelve processes, which can be able to improve the metropolitan governance capacities, reveals that these selected regions indeed apply more operational variables than institutional reforms, as deduced from the next Table 1, showing greater efforts towards innovation in the land use management practices. This would initially seem to confirm the provisional hypothesis launched in the previous figure 1, which suggests that the regions currently invest more in operational processes, based on their accumulated experience. However, a closer look reveals that this difference is only the case of the Paris region (Ile-de-France), which in fact currently places its focus on the planning practices, whereas the institutional context maintains the regional and supra-municipal democratic legitimacy.

Table 1. Processes that are currently underway in metropolitan regions: Madrid (M), Barcelona (B), Paris (P) and Lisbon (L).

\begin{tabular}{|c|c|c|c|c|}
\hline Institutional reforms & M & B & $\mathrm{P}$ & $\mathrm{L}$ \\
\hline $\begin{array}{c}\text { Simplification of the regulatory framework for the } \\
\text { planning system }\end{array}$ & & & & \\
\hline $\begin{array}{c}\text { Decentralisation of State or regional government } \\
\text { powers }\end{array}$ & & - & & \\
\hline Loss of municipal powers to the metropolitan level & & $\bullet$ & & \\
\hline Technical resources for metropolitan coordination & & $\bullet$ & & \\
\hline Supra-municipal democratic legitimacy & $\bullet$ & & - & \\
\hline Supra-municipal political leadership & $\bullet$ & $\bullet$ & & \\
\hline \multicolumn{5}{|l|}{ Innovation in territorial planning practices } \\
\hline Business initiatives for spatial planning & $\bullet$ & & & \\
\hline Citizen involvement in planning strategies & & & & \\
\hline Integration of sectoral strategies in planning & & $\bullet$ & & \\
\hline Continuous assessment of plans & & & & \\
\hline $\begin{array}{l}\text { Assessment of technical alternatives in important } \\
\text { projects }\end{array}$ & & & & \\
\hline Voluntary inter-municipal cooperation & & • & - & \\
\hline
\end{tabular}

In contrast, greater balance is registered in the other cases, despite the fact that there are operational processes underway in all regions, whose innovation can effectively result from a progressive effort to improve the territorial practices. In this sense, it is possible to highlight the variables that reveal certain continuity in time and can be considered important for metropolitan governance, such as initiatives by socio-economic agents in the Madrid region, voluntary inter-municipal cooperation in the Barcelona region, integrated assessment of technical alternatives in Ile-de-France and also citizen participation in planning, which is being partially implemented in Lisbon.

Starting with the Madrid case study, there is no doubt that this region has relatively few processes currently underway, in terms of this conceptual analysis model. In the next figure, the arrow direction is showing the possible recent evolution dynamic, because the first actions of the regional government (such as the management of the Planning Guidelines and the innovation in the legislative framework of 1984) were not accompanied by an integrated planning, despite the establishment of the Bases for the Regional Territorial Strategy Plan in 1996.

In the last decades, the Madrid region political leadership was more focused on investment in large-scale mobility infrastructures, generating an unprecedented urban grow. It is true that the institutional conditions are very favorable in this case, and it does not decrease the governance capacity, but the evolution in coming years is uncertain. It is possible to recognize, however, that the professional experience, within territorial management, may solve the lack of comprehensive spatial planning.

As an important asset in Madrid, one can highlight the civic society initiatives in land use management processes, in line with the policy for achieving the stakeholder's involvement. That's the case of the interactions between the municipalities and the "new" regional powers, after the Spanish transition to democracy in the late 1970s. In recent years, even the trade unions have increased attention on spatial planning, recognizing that "the city, as a physical and social space, and the processes involved in its construction (who builds how, where and for whom) are wholly matters for consideration for a trade union, which cannot and should not remain on the margins of the urban planning debate. In the final instance, the city (...) should be seen as a 'social salary' that completes complements and enriches the direct salary" [12].

Furthermore, since 1981, the Madrid Independent Business Confederation (CEIM) has been carrying out work to promote spatial planning, also on the metropolitan scale, and in particular with the purpose to highlighting the possibilities for establishing economic activities. In recent years, it has published a number of reports offering a more comprehensive and pedagogic view of planning: regulations, urban landscape, energy efficiency and proposals for the Regional Territorial Strategy Plan.

In the other regions, it is possible to identify possible short-term evolution dynamics. In Barcelona, one must recognize that there were "always" processes underway to improve metropolitan governance. In the future, these collective efforts will certainly continue: regarding the decentralization reforms of the regional government, the actions of the new Barcelona Metropolitan Area consortium (AMB) and also the practices that foster networking with the socioeconomic agents, thus justifying a positive evolution trend (figure 3), given that we haven't to "start from zero because the territorial governance structure is already in place" [13].

In Barcelona, it is clear that the voluntary cooperation between municipalities is a progressive process of 
noteworthy actions in strategic and territorial planning. But even before its institutional stabilization in the current legal form of Consortium, the Mancomunidad of municipalities had gathered considerable experience in project development and so acquiring technical capacities for promoting infrastructure, housing and public space projects, to the benefit of the whole region. The Metropolitan Institute for the Promotion of Land and Heritage Management (IMPSOL) was set up in 1992 and built social housing complexes in joint operations with the local authorities, offering different typologies for younger families, which could not find the same product in conventional developments. The land acquisition policies, carried out in agreements with the peripheral municipalities, contributed to strengthening trust in cooperative work.

In the Paris case study, the processes that are underway reveal a considerable level of commitment to innovation in the spatial planning practices, facing an apparent stability of the institutional framework. However, it is precisely in the context of the relationship between the powers where the main changes are being played out, with the French central government and the capital city addressing the leadership of the metropolitan project. According to Ariane Azéma [14], "this trend will contribute to political balances, to institutional negotiations, including with the State, to development project dynamics and also to international visibility. It will also be conditioned by a fiscal and financial review. But it cannot be dissociated from a sense of belonging and identity - elements that are equally decisive for governability and regional organization". This indicates institutional challenges, which together with the implementation of inter-municipal strategies will be the most important processes for improving governance capacities in coming years.

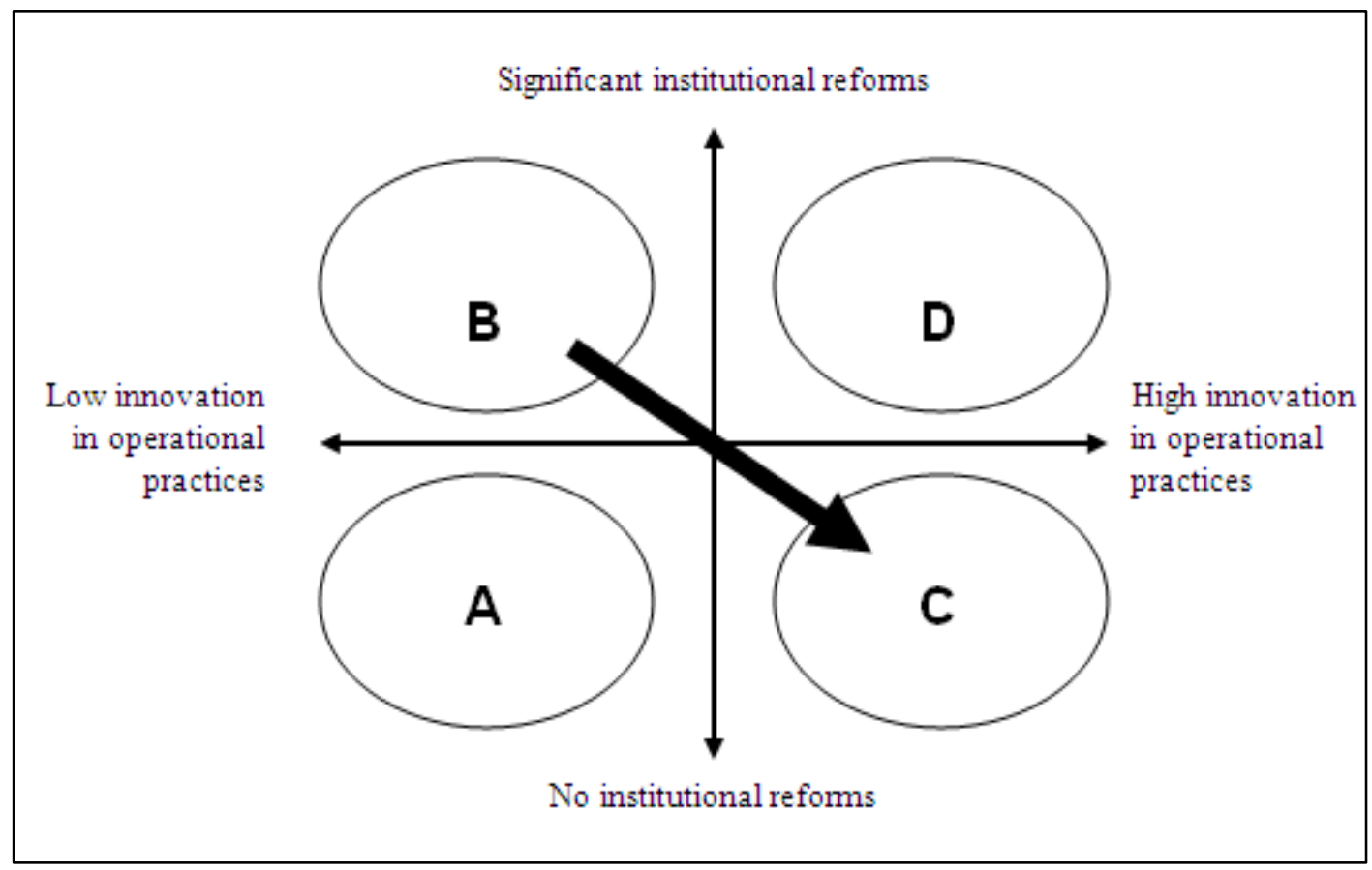

Figure 1. Theoretical positions of the regions, in terms of their processes in progress reforms at the institutional level, and innovation in operational spatial planning practices. 


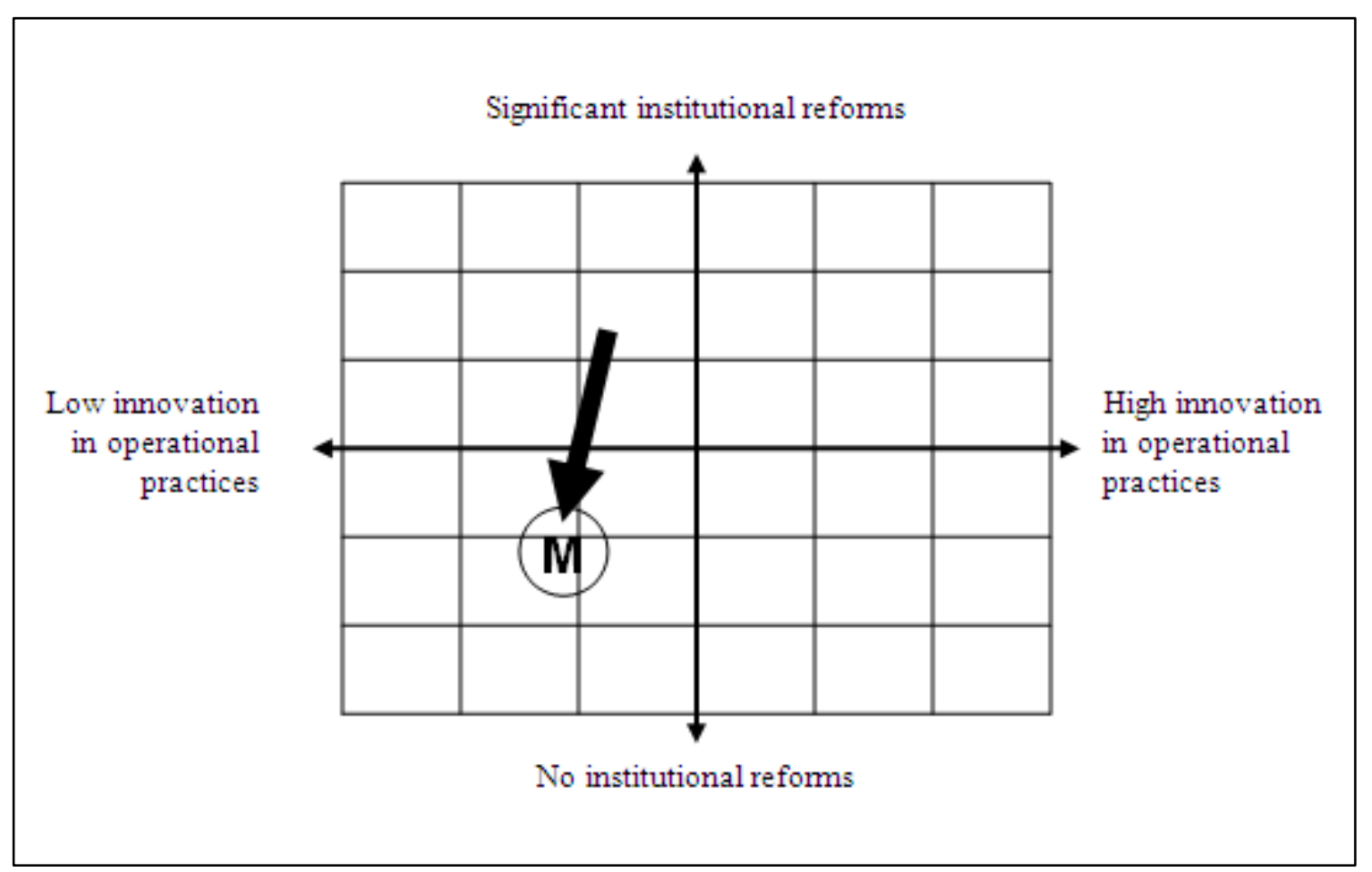

Figure 2. Territorial governance dynamic in the Madrid region (M).

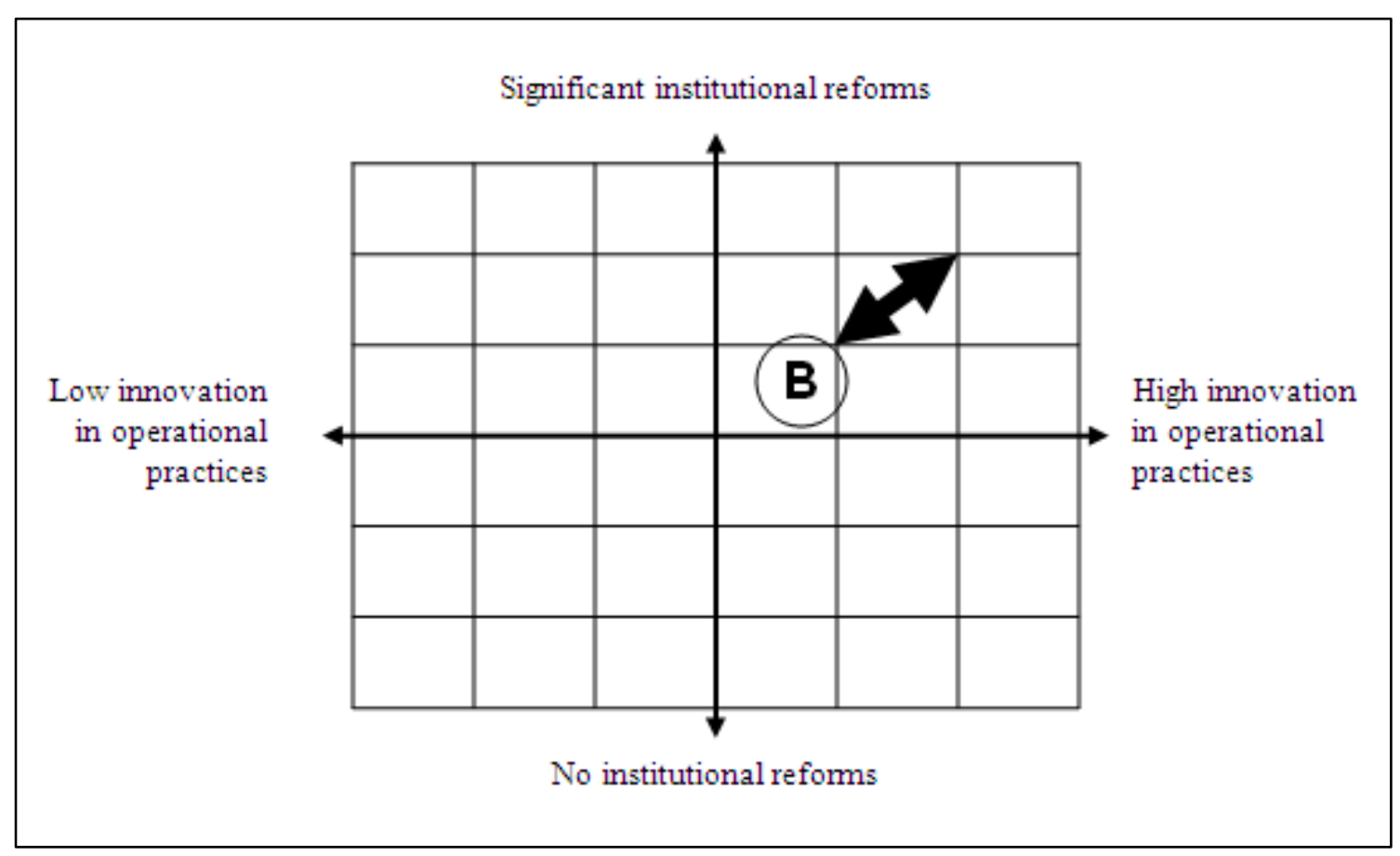

Figure 3. Territorial governance dynamic in the Barcelona region (B). 


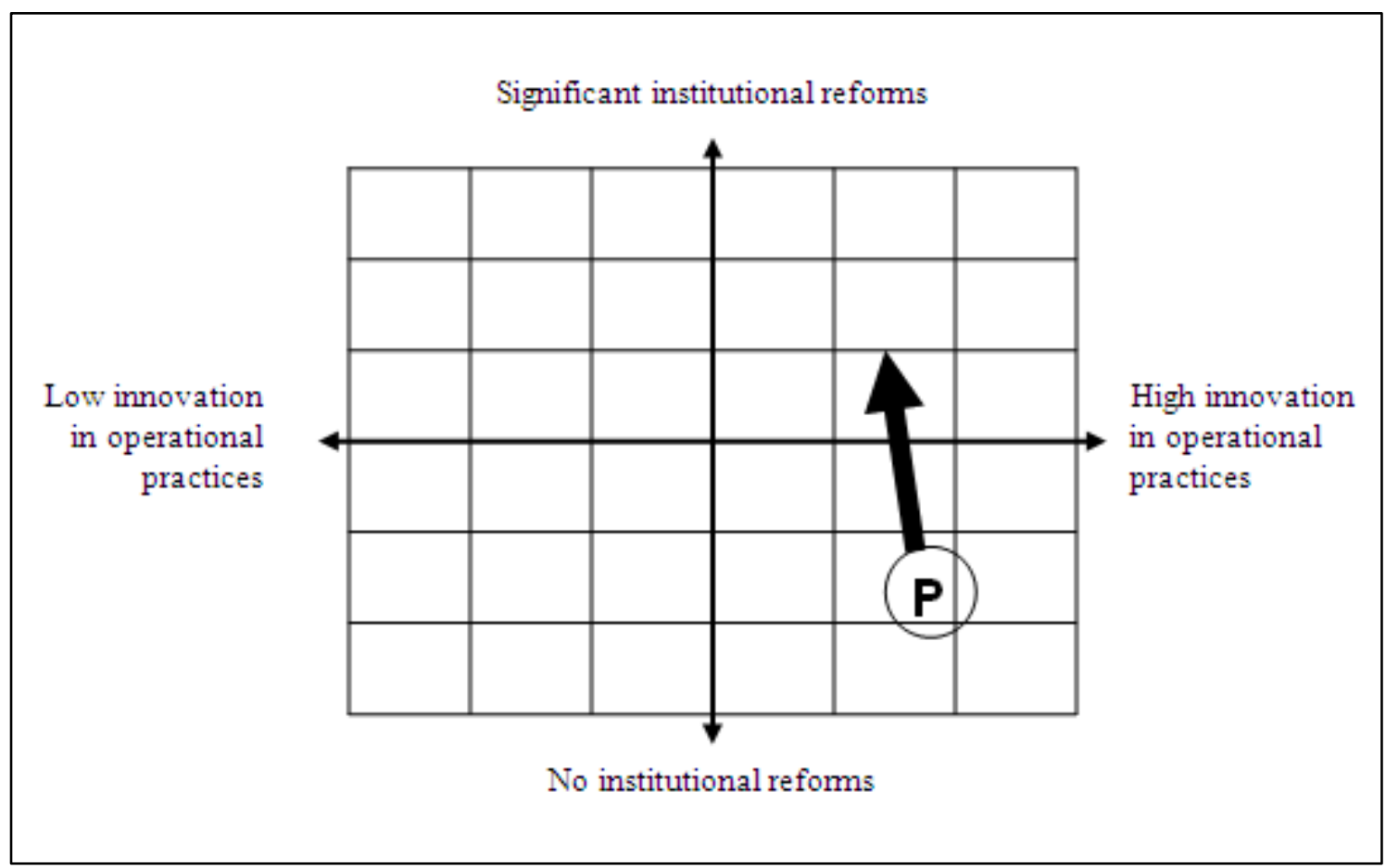

Figure 4. Territorial governance dynamic in the Paris region (P).

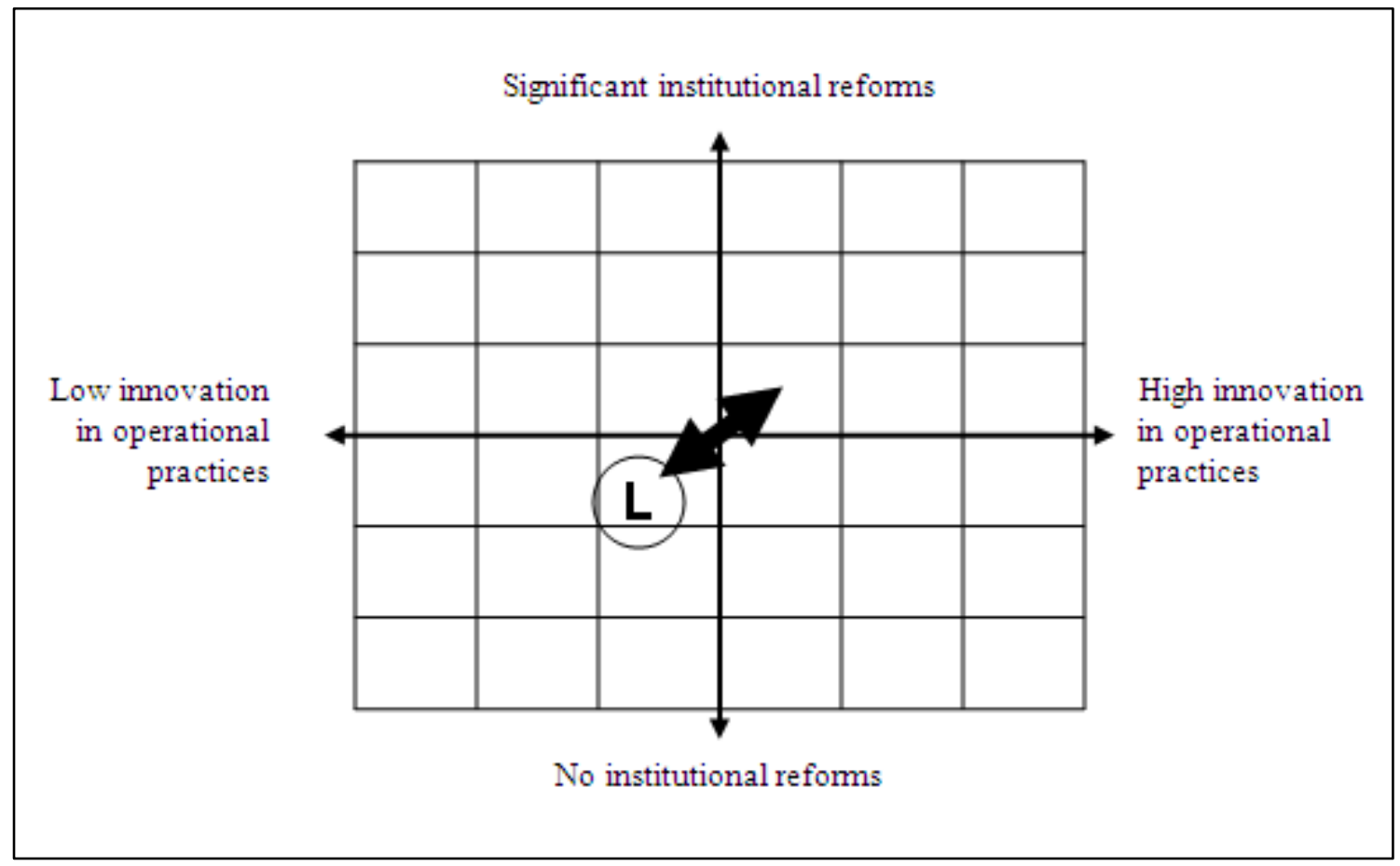

Figure 5. Territorial governance dynamic in the Lisbon region (L). 


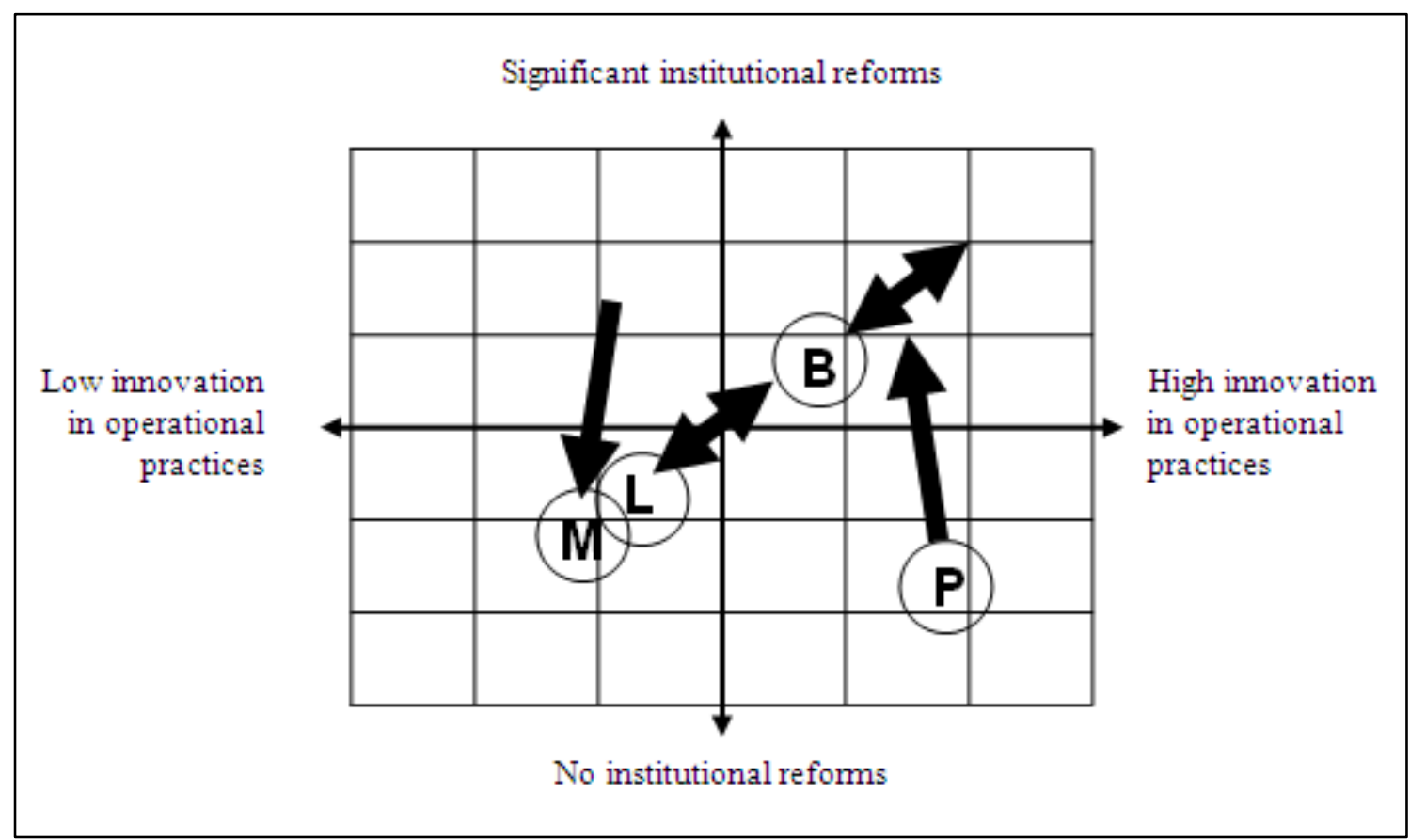

Figure 6. The dynamics of metropolitan governance in four regions - a comparative perspective.

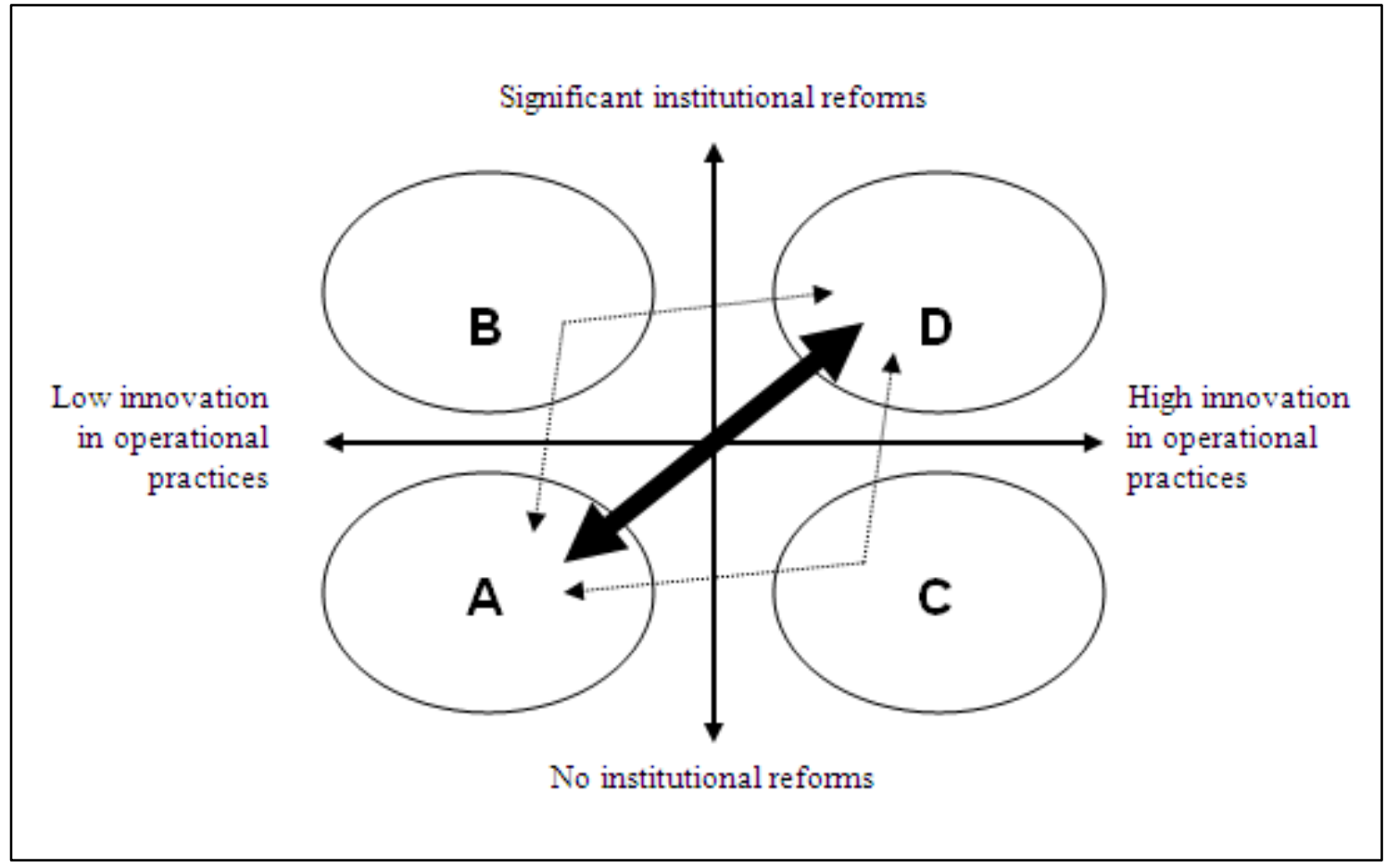

Figure 7. The balance between the two dimensions of metropolitan territorial governance

The assessment of different alternatives for large-scale planning projects is a process underway in the four regions, but it takes on a more ambitious scale in Paris. In 2008, the central government launched a consultation process to discuss ideas for Ile-de-France and central city development. The proposals remain into a certain level valid, given that the aim was not to select a specific project, but to open up the metropolitan debate to the whole society, including international experts from various countries. The whole regional territory thus became the object of study, and not just one important infrastructure, generating reflection on different conceptual models.

The Regional Council Schéma Directeur presented also in 2008 is thus complemented by other perspectives, as the invited international teams recognized. This process gave rise to proposals with different objectives and on varying 
scales - a connection with Le Havre, to form a linear metropolitan area to the sea, or concepts for new infrastructures and centralities. There were three recurrent themes amongst the projects: the linking of land use management and transport; the strengthening of urban identities; and the ecological concerns [15]. The Descartes Group, for example, presented 3 suggestive targets: 20 square meters' more per dwelling; 30 min. less mobility per day; and a decrease of 2 degrees Celsius in temperature.

Clearly, this process is not innocent, as it contributed to strengthening the intervention of the previous "Sarkozy central government" in Greater Paris, which was given a Secretary of State office to promote its international competitiveness. Complementary therefore to the municipal options and those of the Conseil Regional d'Ile de France, it is possible to identify a central policy for the metropolitan region. This is justified because "the State must take an interest in territories that produce roughly one-third of the national wealth. While the local authorities naturally play the role of managers, they currently do not have the necessary coordination instances" [16]. This is confirmed by an historical reading, given that all French leaders have endeavored to leave their mark on the city, like François Mitterrand in the 1980s and 90s.

Finally, in the greater Lisbon region, there is an acknowledged need for effective changes in matters of responsibilities, resources and regulatory organization, but also opportunities for improving territorial planning practices. However, it all seems to depend on structural reforms advancing the administrative decentralization of the State and the building of a technical and political leadership at the metropolitan level, as indeed has been previously argued [17]. The Lisbon region theoretical position in the governance conceptual framework, based on the processes currently underway, reveals the same uncertainty that Madrid.

The important processes that are underway include the consultation periods in the preparation of land use management plans. In this area the Lisbon region has acquired some experience, above all in the context of the work carried out by the Regional Coordination and Development Commission under the leadership of António Fonseca Ferreira. At the national level, one important example, from 2006, was the improvement in the National Programme for Land Use Management Policy after a period of public consultation; this could be replicated in the metropolitan planning revision.

Resuming up this comparative analysis, it is possible to confirm that the governance processes studied in these four metropolitan regions present various differences, which respond to the different evolution of geographic and organizational conditions. The Madrid and Lisbon regions revealed major problems in promoting a comprehensive territorial planning at metropolitan scale, while the Barcelona and Paris regions show the development of institutional reforms paired with an effort towards innovation in the operative practices. Therefore, the conclusions of this research present some findings related to the two metropolitan governance dimensions.

\section{Conclusions}

A contrast analysis of the processes underway and those considered the most important in each region by the experts interviewed, revealed four particular assets, which, at different stages of implementation, show that they are able of producing positive effects, improving the capacities of metropolitan governance. These processes are: the initiatives by social and economic agents in territorial planning in the Madrid region; the voluntary cooperation between municipalities in the Barcelona area; the assessment of different projects in the Paris region; and the public participation in planning strategies, albeit at a still timid level, in Lisbon. All of these processes can be considered elements associated with the more operational and technical dimension of spatial governance, which suggests that one can confirm the provisional hypothesis that there are good practices in each region, worthy of particular attention with a purpose for innovating on the basis of accumulated experience, as opposed to always rethinking the institutional context in which these processes take place.

This finding can indeed be confirmed, but a more in-depth knowledge of the four regions means that this conclusion must be qualified, for 3 particular reasons. Firstly, in the cases of Madrid and Lisbon, the positive effects of these processes can be seen as a response from the socio-economic agents to the lack of institutional actions that are not carried out in the best way: in Madrid it is maybe the lack of a comprehensive planning framework that identifies the importance of civic society initiatives, and it is yet to be seen if this situation can only be solved by a political change at the regional body; and in the Lisbon case study those opportunities for the public discussion of the plans are useful for consolidate proposals that should, perhaps, be already better prepared, meaning that the regulation solves finally a persistence problem of coordination.

Secondly, there are also important reforms underway, related to the political dimension of governance, which will be important for strengthen the metropolitan capacities. These include the supra-municipal leadership in Barcelona and the decentralization of powers and simplification of the planning system in the Lisbon region. This is justified by the "dual" nature of these territorial management processes, given that there is a noticeable trend, from the political perspective, towards thinking that the plans can be perfect technical solutions and, from the planning professional viewpoint, to frequently request changes in the institutional framework.

The urban planners usually comment that territorial problems can only be solved through new responsibilities or other administrative bodies (the "institutional fallacy" that Michael Hebbert refers to). But the results of this research 
indicate that, in opposite direction, the good operational processes underway are required to motivate such structural reforms.

The third reason is that, regarding the governance system in the conceptual analysis model, any region presents the preference to underway their potentially innovative practices in technical processes rather than overcoming the need to reform the organizational and institutional framework (figure 6). It is true that one could place the Paris region in that position in relative terms, perhaps on account of its greater experience in the regional planning, but the dynamic evolution indicates that there are also important "power struggles" underway at the metropolitan space: the capital city, the inter-community relations, the Regional Council and the central government. In this case, it is acknowledged that fragmentation of powers is even positive, making it possible to achieve effective consensus. In Madrid and Lisbon, the processes in practice are nowadays more limited, possibly because the structural conditions does not favor that innovation, a "thesis" that the Barcelona region confirms with its positive situation, given that the establishment of better planning practices stimulates relevant institutional reforms. The trends, both in Paris and Barcelona, thus reveal this two-way relationship - two dimensions that can feed each other progressively.

This remark is boosted further in the Barcelona region, considering its strong tradition of planning on the metropolitan scale, which is manifested both in the political efforts to improve the conditions of governance in the "Mancomunidad de municipios" and in the promotion of the "everyday functions" through the environment, transport, social housing and public space management bodies, in addition to the territorial strategy, shared with the regional government.

The conclusions confirm that progressive innovations, based on the specific metropolitan accumulated experience, in terms of strengthen the participation and social capital, land management strategy and voluntary cooperation in projects can lead to structural changes in the institutional governance context, in terms of responsibilities, resources and leadership. In other words, these are dynamic processes that influence each other in a permanent ongoing evolution, rendering the useless to configure "a priori" a perfect framework in theory.

The contribution that results from this research is that metropolitan governance capacities will improve with the opening of each region for the implementation of these types of processes. They can be achieved with sufficient flexibility, considering that the development of one process produces changes in others. This mutual influence is thus verified, although this doesn't mean that there are no indirect trajectories (figure 7): in the Paris region, the land management practices underway may require political changes, while in Madrid there is less activity, possibly as a result of a high level of institutional stability, in the recent years.
In this conceptual model analysis, which confronts the relations between the two main dimensions of metropolitan governance, the identifiable movement trend is therefore, not from the field $\mathrm{B}$ to $\mathrm{C}$, but between the fields $\mathrm{A}$ and $\mathrm{D}$, because as the technical capacities are increasing new challenges emerge, that require other specific political responses. Even if only one of these processes is being underway, this will change the governance balance and stimulate the form of other actions. If it was obvious that institutional reforms lead to new challenges in planning practices, the research argues that the opposite direction is also true - that operational processes give rise to structural changes, proving their corresponding influence on responsibilities, resources and leadership, given that any of these political contexts are fixed or stable.

\section{Acknowledgements}

We are very grateful to 22 experts, for their relevant contribution to this research: Abel Enguita, Ricardo Méndez, Rafael Mata, Enrique de la Villa Polo, José Manuel Rodríguez Álvarez, Luis Felipe Alonso Teixidor and Pedro Ortiz (concerning their knowledge from the Madrid region case study), Mónica Madrigal, Juli Esteban Noguera, Malcolm Burns and Albert de Pablo (Barcelona), Pierre Mansat, Elsa Vivant, Christian Lefèvre, Ludovic Halbert and Martine Liotard (Paris) and João Cabral, Pedro George, Carlos Pina, Hipólito Bettencourt, Maria do Rosário Partidário and Rosa Branco (Lisbon).

\section{REFERENCES}

[1] World Bank. World development Report 2009: Reshaping Economic Geography. World Bank Publicatons, Washington, 2008.

[2] W. Salet, A. Thornley, A. Kreukels. Metropolitan Governance and Spatial Planning. Comparative Case Studies of European City-Regions. Spon Press, London, 2003.

[3] B. Jouve, C. Lefèvre. Métropoles ingouvernables. Les villes européennes entre la globalisation et décentralisation. Elsevier, Paris, 2002.

[4] G. Clark. The Business of Cities. The Vital City, European Urban Research Association Conference, Glasgow, 2007.

[5] A. M. Sigmund. En route vers las citoyenneté européenne. A face oculta da governança: cidadania, administração pública e sociedade, Instituto Nacional de Administração, Lisbon, 2003.

[6] J. M. Fernández Güell. Planificación Estratégica de Ciudades. Nuevos Instrumentos y Procesos. Editorial Reverté, Barcelona, 2006.

[7] M. Belil. La ordenación de las áreas metropolitanas europeas. In: A. Font, Planeamiento Urbanístico. De la controversia a la renovación. Diputación de Barcelona, 2003.

[8] H. Heinelt; D. Kubler. Metropolitan Governance. Capacity, 
Democracy and the Dynamics of Place. Rouledge, London, 2005.

[9] P. Healey. Las fortalezas y debilidades de la aproximación comprensiva a la planificación regional: la experiencia Británica. La ciudad global ¿Cómo gestionarla? Consejería de Medioambiente y Ordenación del Territorio de la Comunidad de Madrid, 1996.

[10]R. Florentino. Parámetros de gobernabilidad territorial metropolitana. Cadernos Metrópole $\mathrm{n}^{\circ}$ 20. EDUC, São Paulo, 2008.

[11] M. Hebbert. El Grupo de Trabajo - Task Force - y el nuevo enfoque del urbanismo británico. Urban $\mathrm{n}^{\circ} 4$. DUyOT-ESTA, Universidad Politécnica de Madrid, 2000.

[12] R. B. Valenciano. Otro Urbanismo es Posible. Siete miradas sobre Madrid. Fundación Sindical de Estudios y Comisiones Obreras de Madrid, Ediciones GPS, Madrid, 2007.
[13] J. Echániz. Un sistema local para el gobierno del territorio en la sociedad de las redes: el caso de Cataluña. In: J. Subirats. Redes, territorios y gobierno. Nuevas respuestas locales a los retos de la globalización. Diputación de Barcelona, 2002.

[14]A. Azema. Métropole francilienne: une gouvernance à la croisée du local. Les Cahiers $n^{\circ} 151$. Institut d'Aménagement et d'Urbanisme de la Région Ile-de-France, Paris, 2009.

[15] M. Liotard, A. Duguet, V. Fouchier, P. M. Tricaud. Grand Pari(s), acquis d'une consultation hybride. Les Cahiers $n^{\circ} 151$. Institut d'Aménagement et d'Urbanisme de la Région Ile-de-France, Paris, 2009.

[16] N. Sarkozy. Le Grand Paris. Interview by F. Gilli and C. Poy. L'Architecture d'Aujourd'hui no 376. Paris, 2010.

[17] R. Florentino. Procesos innovadores de gobierno y ordenación del territorio. La región metropolitana de Lisboa en perspectiva comparada. $\mathrm{PhD}$ thesis. DUyOT-ETSA, Universidad Politécnica de Madrid, 2011. 